This is an electronic reprint of the original article. This reprint may differ from the original in pagination and typographic detail.

Author(s): Lehtomäki, Elina; Moate, Josephine; Posti-Ahokas, Hanna

Title: Global connectedness in higher education : student voices on the value of crosscultural learning dialogue

Year: $\quad 2016$

Version:

Please cite the original version:

Lehtomäki, E., Moate, J., \& Posti-Ahokas, H. (2016). Global connectedness in higher education : student voices on the value of cross-cultural learning dialogue. Studies in Higher Education, 41(11), 2011-2027.

https://doi.org/10.1080/03075079.2015.1007943

All material supplied via JYX is protected by copyright and other intellectual property rights, and duplication or sale of all or part of any of the repository collections is not permitted, except that material may be duplicated by you for your research use or educational purposes in electronic or print form. You must obtain permission for any other use. Electronic or print copies may not be offered, whether for sale or otherwise to anyone who is not an authorised user. 


\title{
Global connectedness in higher education: student voices on the value of cross- cultural learning dialogue
}

\begin{abstract}
The study explores how sense of global connectedness can be enhanced by creating opportunities for cross-cultural dialogue in higher education. Thematic analysis of randomly selected 15 learning journals, students' reflections on their learning during an international seminar was used to identify students' significant learning experiences. The results emphasise the added value of diversity (geographical, disciplinary, cultural, social) among students, faculty and invited presenters for creating meaningful learning. Furthermore, they suggest that designing an integrated approach of contents, contexts and activities for critical engagement in global dialogue and knowledge generation in higher education can open up new perspectives to students in education and thereby increase their sense of global connectedness. The research addresses internationalization of higher education, contributes to the development of international study programmes and provides means to enhance inclusion of global issues in higher education policies, curricula and practice.
\end{abstract}

Key words: cross-cultural learning, learning dialogues, higher education, global connectedness, significant learning experiences, internationalization

\section{Introduction}

Globalised knowledge economy urges higher education institutions to move from

internationalization to global dimensions with emphasis on learning and learners' perspectives.

Higher education institutions are to prepare global citizens for the uncertain future, where people, work and all matters are more interconnected than ever before. Disciplinary boundaries, subject contents and local contexts no longer correspond to the needs of individuals, employers and societies (Crosling, Mahendhiran and Vaithilingam 2014; Istance and Dummont 2010).

Competences required in the globally connected world include understanding own values and attitudes, critically reflecting knowledge and information, analysing situations and perspectives, linking own views and local issues to broader global contexts, finding options, justifying choices and communicating (Bourn 2014; Jones and Caruna 2010; Scheunpflug 2011) and interacting with 
diverse peers (Denson and Bowman 2013).

Two international higher education networks have recently underlined the importance of widening perspectives and of enhancing understanding of the interdependence between countries, institutions and people (IAU 2012; European Multi-Stakeholder Steering Group on Development Education 2010). Critical engagement of citizens in global issues is deemed increasingly significant for ensuring democratic culture, peace and sustainable development. The challenge for higher education institutions is to find effective ways to engage students in global issues. This challenge has been partly addressed through the internationalisation of curricula and the development of extra-curricular activities, aiming to ensure that students who participate in international mobility and non-mobile students can benefit from internationalisation and gain global competences (IAU 2012).

Mainstreaming internationalisation in universities' core activities is recommended for greater impact (Kehm and Teichler 2007). Indeed, Kehm and Teichler (2007) argue that failure to realise internationalisation to a higher degree at home may lead to a polarisation of winners and losers, i.e. those who participate in international student exchange and those who do not. Previous research has shown that despite genuine aims for internationalisation, disciplinary cultural dynamics in higher education institutions and the inability of current pedagogic practices to create crosscultural learning dialogue can work against the internationalisation efforts (e.g. Miller-Idriss and Shami 2012; Tian and Lowe 2009; Schweisfurth 2012) losing out on the potential to create global awareness. Studies on internationalisation at home in a university context highlight the need for planned, structured interventions (Jon 2013) and the importance of institutional support for building intercultural relationships (Bennett, Volet and Fozdar 2013). 
This is not only a top-down initiative, however, as "more and more students wish to have a greater sense of global connectedness" in turn challenging universities "to ensure this interest becomes the dominant voice in promoting their international outlook rather than as subsidiary to one based on market share and economic need" (Bourn 2010, 27). The concept 'global citizenship' (Bourn 2014) has been introduced to guide both contents and pedagogical principles to develop understanding of global issues and critical thinking. According to Bourn $(2010,2014)$ more research is needed on how students perceive global issues in their higher education studies, relate themselves to the global contexts and what motivates students to engage in the global society.

Previous studies focusing on students' experiences of internationalisation and mobility (Gargano 2009; Tian and Lowe 2009; Russell and Vallade 2010) provide contrasting views on institutional internationalisation. These studies emphasize the importance of researchers and practitioners stepping outside standardized practices to develop innovative programs and realize the potential of international student mobility. In line with the European and international trends the current Strategy for the Internationalisation of Higher Education Institutions in Finland 2009-2015 (OKM 2009) set five primary aims for internationalisation:

1) a genuinely international higher education community,

2) increasing the quality and attractiveness of higher education institutions,

3) promoting the export of expertise,

4) supporting a multicultural society, and

5) promoting global responsibility.

According to a recent evaluation (Välimaa et al. 2013) the international degree programmes in Finnish higher education institutions have good quality but more efforts are necessary to integrate learning activities and ensure that all students pursue multicultural competences. 
The changing and increasingly global contexts call for continuous questioning of internationalization's values, purposes, goals and means. The academic aims outlined above, whilst aiming to advance scientific knowledge and organisational change through internationalization, they are also suggestive of global competition. The importance of international prestige and impact of ranking systems have been recently brought up as the adverse consequences of internationalization (IAU 2012; Stromquist 2007; Taylor et al. 2013). In the midst of policy makers and higher education administrations drive to increase internationalization, Bourn $(2010,23)$ raises the question of how students perceive "their own role, learning priorities and engagement in society". This important question not only challenges researchers to engage students in the on-going dialogue around internationalisation, but also challenges researchers to recognise what constitutes a meaningful learning experience for students. We turn to this issue below before introducing our research project.

\section{Meaningful learning and internal dialogues}

Cognitive and socio-cultural educational research suggests that students construct meaningful learning, based on their previous knowledge and experiences, through internal dialogue (Novak and Gowin 1984; Novak 2002) and legitimate participation (Wenger 1998, 2003). The learning dynamic emphasised in these theories foregrounds acculturation into existing practices. With regard to internationalisation the existing - or ideal - practices include the need to understand and value different perspectives, recognising the impact of globalisation on relations between people and communities around the world (Bourn 2011). The complexity of this process is represented in Fink's (2013) conception of integrated dimensions of significant learning experiences for guiding higher education teaching (Figure 1). In this figure the need to engage with other, as well as the acquisition of knowledge and practical action, are presented as key components in significant learning experiences suggesting that meaningful learning is more than "head" knowledge, but also 
involves "hands", i.e. action, and "heart", i.e. caring. In the midst of this complexity, it is important to look more closely at the learning dialogues with self and other often associated with meaningful learning (cf. Renshaw 2004; Twiner et al. 2014).

Figure 1. Fink's taxonomy of significant learning experiences

From a Vygotskian perspective dialogues with self and other allow students to more consciously work with notions before they are internalised (Vygotsky, 1980). A Deweyan perspective adds the notion of responsibility to this process with critical reflection being an important step towards taking responsibility for one's participation in the world, going beyond habitual ways of being and doing (Dewey 1922 cited in Biesta and Burbules 2003; Klein 2013). This is no easy process, however, as significant struggles can take place as conscientious participants wrestle with new ideas and responses (Bakhtin 1981; Moate 2014). These different yet complementary views of dialogue go some way towards explaining why dialogues as a form of reflection and engagement can support transformative learning processes. We would suggest that encouraging students to engage in learning dialogues with self and other through discussions is also one way in which students can begin to engage in the wider discussions around important issues in this case, Education for All. In our study these learning dialogues are recorded in the learning logs (cf. Merceia, 2013) of the participants.

\section{Context for the study}

This study was inspired by student feedback on an international 'Education For All' (EFA) seminar in Finland in 2011. The participatory seminar was one of the practises to internationalize higher education and to increase knowledge concerning global issues in education. The theme of the 
seminar was 'Critical Issues' in the global Education For All process, coordinated by UNESCO' . The seminar was organized by the University of Jyväskylä ${ }^{2}$, a world-class university in education sciences and teacher education. The programme included formal talks as well as reported experiences that significantly differed from the day-to-day experiences of many participants (see Appendix 1, Seminar programme). The interactive format and range of pedagogic, as well as information-sharing, activities was hoped to stimulate discussion and critical reflection and the learner log was intended to encourage students to critically think about their learning through the seminar. The organizing team included voluntary students and faculty at the University of Jyväskylä. The invited presenters represented the home university and collaboration partners in the global South and North, i.e. universities and governmental and civil society organizations.

There were 125 participants from over 30 countries. Students were eligible to earn study credits for active participation with a reflective learning journal. Most of the students who completed the learning assignment had education sciences as their major, others majored e.g. in information and communication technology, music education, social sciences and philosophy. The students' group comprised international visiting students and Finnish and international degree students, i.e. all studied at the University of Jyväskylä in Finland at the time of the seminar. Regardless of their field and level of study, the students were instructed to report on 1) what they learnt and 2) how they think this learning will influence their studies and future work, and 3) to reflect on the meaning of the global EFA process. Alternatively, students could also choose to participate without writing learning journals and earning study credits. The learning journals were read and assessed by two faculty staff. Although the seminar was not initially intended to constitute a research project, the overwhelmingly positive response of the students that the seminar had

\footnotetext{
${ }^{1}$ UNESCO: http://www.unesco.org/new/en/education/themes/leading-the-international-agenda/educationfor-all/

${ }^{2}$ University of Jyväskylä, Faculty of Education: https://www.jyu.fi/edu/en
} 
exceeded their expectations as a significant learning experience called for an inquiry. The research questions used to conceptualise the phenomenon (applying Biesta 2013) are as follows:

1. what significant learning experiences are present in the learning journals?

2. what were the conducive learning contexts that supported the significant learning experiences?

3. what sense of global connectedness is present in the learning journals?

\section{Data and analysis}

For this study, 15 of the 40 learning journals concerning the international EFA seminar (see Appendix 1) were randomly selected for analysis. The data selection included journals by Bachelor, Master's and doctoral students. No information was available with regard to the earlier assessment of the journals for grading and crediting. The personal details of the students, including the level of studies, were removed for anonymity. The length of the learning journals ranged from four to six pages, four being the minimum requirement. One student commented "lots of thoughts came to mind which got me reflecting a lot" $(\log 5)$. When presenting the findings, learning journals are referred to as "logs" with numbers, to protect the students' identities.

We applied a thematic analysis (Braun and Clarke 2006; Russell and Vallade 2010) in the initial analysis of the logs to identify expressions of significant learning in the learning logs. Having carefully read through the journals to gain an overall understanding of the material three themes were identified for further analysis: 1) significant learning experiences, 2) conducive learning contexts and 3) expressions of the sense of global connectedness. These themes were used as key headings in the data analysis tables and as the logs were more closely analysed statements referring to significant learning experiences were added to the table. These statements were often prefaced by, for example, "I came to understand", "had a really huge influence on me" and "I learnt for the 
first time". Following these introductory words, the students reflected on learning something new, deepening their understanding, realizing a new way to think or ask questions, i.e. these experiences could also be called as 'epiphanies'.

The second round of analysis focused on the conducive learning contexts identified in the learning journals. This led to characterising the essence of learning activities and methods that supported students' significant learning through the students' own words and experiences (see Table 2). In the final round of analysis, expressions of the sense of global connectedness were analysed to understand how the learning contexts and significant learning experiences contributed to enhancing students' sense of global connectedness. Through this approach we hope to recognise student voice as a contributor to transformation and change in education (Seale 2010; McLeod 2011; Lehtomäki, et al. 2014) and to recognise the complexity of learning associated with a concept such as global connectedness.

\section{Findings}

\section{Question 1: what significant learning experiences are present in the learning logs?}

The thematic analysis of the significant learning experiences identified seven themes characterising various dimensions of learning. These themes are depicted in Table 1 with quotations showing examples of the analysed material and the connection with Fink's model of integrated dimensions of significant learning experiences.

Table 1: Themes of significant learning experiences identified in students' learning journals

These themes highlight the complexity of significant learning experiences. Recognising the limitations of existing understanding (theme 1), problematizing assumptions (theme 4) and 
readiness to engage with others (theme 2) in different, perhaps, novel ways (theme 3 ) highlights learning how to learn as a fundamental relationship with self, other and the nature of coming to know. When seen in this light, learning how to learn creates the space for new understanding

(theme 5) and foundational knowledge anticipating that "head" knowledge translates into action or the application of knowledge. In our dataset, the desire to apply understanding resonates with the recognition of personal and shared responsibilities (theme 6), seemingly motivated by caring for others an intrinsically human characteristic, as well as the comprehension that although problems may be the result of a particular context nevertheless by sharing problems, expertise and understanding positive change can be anticipated (theme 7). On the basis of the seven main themes of significant learning experiences, the second round of analysis sought the learning activities and contexts which, according to the students, contributed to their significant learning experiences.

\section{Question 2: what were the conducive learning contexts that supported the significant learning experiences?}

Five types of interactions arose above other forms of learning activities and contexts, including participatory theatre, mixed discussion groups, cross-cultural encounters, learning café and dark café. A participatory theatre group in education of young actors had studied the 2012 EFA Monitoring Report (UNESCO 2012) and prepared a session to highlight critical issues in the global EFA process with a focus on the country-specific context of Finland. The interactive form of theatre was a success, “opening eyes" (log 17$)$, because "everyone was involved and amazed by the way the problems were shown so they jotted down the solutions for improving the system" $(\log 4)$. The students reported how powerful learning experiences they gained through the drama combined with prompted themes for informal discussions and contributions from the participants. Furthermore, they understood the connections of the challenges in one country to the broader context: 
we witnessed a beautiful drama which brought forth some challenges in the Finnish education system. These challenges are equally faced in many educational systems worldwide $(\log 5)$.

The second type of interaction valued by the students as very conducive for learning was the mixed groups, each one comprising students, faculty and invited presenters. Each group had a specific theme to discuss and reflect on critical issues and possible solutions. The participants had the freedom to choose in which discussion theme group they wanted to take part. The atmosphere was found encouraging participation of all and, therefore, the experience "was so enriching" $(\log 2)$.

The discussion ended when the time elapsed, leaving more questions on the minds of the discussants. There are still many aspects of gender discriminations yet unexplored within different contexts $(\log 34)$.

Cross-cultural encounters, formal and informal, that occurred throughout the two-day seminar were significant means to find new perspectives. The effect of the planned variety of active interactions was evident in the learning journals.

The opportunity to be in contact with people from around the world was an amazing chance to see issues from different points of view, but more than that it was exciting to see so many people committed to education around the world $(\log 37)$

Almost every student mentioned in their logs the presentation in Sign Language by a Finnish deaf university student on his academic exchange period in Ethiopia. He explained his university studies in Addis Ababa, observations of everyday life and voluntary work among deaf children who had very limited access to education. The presenter showed his photos, described the challenging situation of deaf children in Ethiopia and emphasised the importance of education for all. 
This was a new experience for me. I have never participated in a presentation of a deaf person, where an interpreter translated his Sign Language into spoken language (log 40)

I was highly inspired by his spirit and his ability to turn his disability into a special ability (log 34)

Two different Cafés were provided during the seminar. The students explained how the Café activities motivated them to understand the importance of broadening perspectives not only through knowledge but by practical personal experiences. One of the Cafés was called 'The Learning Café', a morning session for which doctoral students had selected challenges of the global EFA process, set one challenge written on a piece of paper on each small coffee table in the university cafeteria, reserved for the activity. Two doctoral students guided participants to tables, maximizing diversity around each table. The tasks given for the participants around each table were to find possible solutions to the challenge indicated on the paper in a short time. After that participants were asked to move to another table, mix with a new group of people, see what the previous group had suggested, build on their ideas and make more suggestions. The students found the Café interaction inspiring for changing perspectives.

Café group discussion facilitated [meeting] people in different academic disciplines and widening the knowledge in education and how to find quick possible solution for the education success. Several solutions were proposed which helped to think more suggestion out of what others mentioned $(\log 18)$

Another Café with activities was 'the Dark Café', organized by the local association of persons with visual disabilities, which many students described as an extraordinary event. In the Dark Café there was no light, i.e. one small classroom was made totally dark without any light. Seminar participants were clients, having coffee or tea without light, served and guided by young people with visual disability. 
Discussion about disabilities was not discussion in the true sense of the word, but the unusual experience, because I visited Dark Café. The format of this discussion could not be more concise. In the middle of darkness was very interesting chat with others and I could better imagine how feel blind people within the conversation. At times I thought my eyes were covered with a scarf and cafeteria staff sees. I felt really special feelings (log 38)

Presentations by invited speakers were mentioned only for their contents but one of them, thanks to the personality of the presenter, format and the approach to EFA with both personal and global views created great enthusiasm among the participants. While the presentations by the invited speakers were appreciated for contents not as engaging learning activities, one student commented that "the method of presentation was a little boring... If anything, this presentation made me really think about how to give an engaging presentation!" (log 15). Table 2 summarizes connections between the significant learning experiences (themes) and the conducive learning activities and contexts.

Table 2. Conducive learning activities and contexts contributing to significant learning experiences. The extent of the contribution is highlighted by colour, the deeper the blue the more important the activity and context for learning according to the students.

The pedagogical design of the EFA seminar specifically intended to provide a range of activities and formats for engaging the participants in the key issues raised in the seminar. Nevertheless, a key finding of this inquiry is the way in which the different contexts fostered or supported different dimensions of learning. The participatory theatre, for example, particularly helped the participants to recognise the limitations of their own understanding and possibilities to understand (theme 1), as well as helping the participants to appreciate learning through innovative interactional means (theme 3). The mixed discussion groups, cross-cultural encounters, on the other hand, as well as the 
inspirational presentation of a deaf student teacher supported the development of new understanding (theme 5) as new ways of being in and knowing about the world opened to the participants. It is also interesting to note the way in which the two cafés fostered different learning experiences. In the Learning café the participants began to question their existing assumptions (theme 4) and to recognise their personal and shared responsibilities (theme 6) by engaging in discussion with others. The Dark Café also prompted deeper reflections (theme 2), however the novelty of experiencing something other (theme 3), was a profound experience for many of the participants. These findings highlight the importance of using novel and varied means of engaging with others, as well as the need for space to reflect on what has been, what is and what could be. This leads to our third question specifically focused on the sense of global connectedness present in the learning logs.

\section{Question 3: what sense of global connectedness is present in the learning logs?}

Across the learning journals, the students expressed how they experienced a sense of connectedness among each other and between the challenges in education in different contexts. They discussed their own role, responsibilities and possibilities to enhance education for all through their future work, in collaboration with others, thus highlighting the value of the learning through dialogic approaches. The global connectedness, according to the students, required a personal stance. The main outcome of the significant learning experiences evident in the journals was the understanding of the global EFA process, rather than a distant issue as one that required participation of all and which everyone can contribute to. One participant reflected on how the sense of global connectedness was constructed during the seminar, interpreting the experiences in relation to their generation:

The conference [the EFA seminar] was a place to meet new people, a place to really internationalize. We are generation that is from the beginning raised as a generation of world 
citizenship and global community. Mass media, international companies and trade, EU and traveling possibilities have made on international playground. No longer are we waited to only live in Finland our whole lives like our parents. We as a generation are encouraged to go and study abroad, to learn English and other languages, to learn customs of different countries. EFA-conference made me really think of becoming an exchange student and going abroad to study someday. This is something I've thought for quite some time. Eventually I know I will do it. [..]

I got the feeling that now I'm really part of the international global teaching community. It was a feeling of uniting, a feeling that here we are gathered; the today's generation of educators. It was the feeling of trust; that we are ones being largely responsible for the future generation. It was nice to notice that question of inclusion is not only a hot topic of debate just in Finland but also in other countries as well. It was nice to see so many were enthusiastic about their job ready to make a difference. It felt abundant that in these times of xenophobia people were gathered together in harmony and peace. $(\log 17)$

The students explained how their feelings of belonging and value attached to dialogue were essential to making a difference. Furthermore, they stated that how these feelings should also move people to action. Figure 2 summarises the expressions of the sense of global connectedness and profiles the students' sense of global connectedness in the context of the global Education for All process.

Figure 2. Sense of global connectedness in student learning logs

\section{Discussion}

The seven themes of significant learning experiences highlight the complexity of constructing meaning, in this case concerning the global Education For All commitments, process and challenges. The integration of a variety of learning activities and contexts, combined with tasks for reflection, i.e. internal dialogue and internalisation on meaningful learning proved empowering. The findings emphasise the importance of engagement in dialogic learning in conducive, cross-cultural contexts. The main outcome of the interactive seminar, evident in the learning journals, was the 
construction of the sense of global connectedness, between the participants, linking the local and global and feeling of belonging to 'a global community' of learners and teachers.

To summarise, the significant learning experiences (Fink 2013) and global connectedness (Bourn 2014) as told by the students consisted of: learning about others enhances learning about self, re-consideration of assumptions, re-evaluation of familiar, recognising the relativeness of problems and global connection not only brings greater awareness, but raises new questions. Thus, the learning outcomes included: 1) professional skills, 2) intercultural understanding and 3) ways of promoting global connectedness in education.

The study achieved its overall aim, to find ways to increase students' engagement in global issues and to develop tools for higher education to provide students with global skills, necessary for realising their potential and contributing to global development, as suggested by international higher education networks (IAU 2012; European Multi-Stakeholder 2010) and recent research (Bourn 2014; Crosling et al. 2014; Denson and Bowman 2013; Scheunpflug 2011). The findings highlight that the contents and key messages of the seminar were well received by the students. Thus the course responded to the call of the International Association of Universities (IAU 2010) to promote globally agreed education targets, such as Education For All and Millennium Development Goals. Also, the recommendations of the DE Watch (2010) to clarify concepts related to global education issues and increasing common understanding through more research and sharing of knowledge and views among academics and practitioners, were realised.

Creativity (as recommended by EUA 2007) in learning activities and contexts, providing chances for cross-cultural encounters and prompting challenging assumptions was clearly appreciated by the students. One of the most powerful presentations was by a Finnish deaf university student on his exchange period in Ethiopia, which, according to the students' journals, 
combined a complexity of elements, i.e. experience in international mobility, making a difference regardless of challenges, showing capability to analyse the significance of education, and highlight connections between the local and global. This suggests that students' perspectives and experiences created a significant connection and provided a powerful example, thus increasing understanding and motivation to act. Altogether, the opportunities for understanding, experiencing and realising were transformative, as one the students wrote "How can I understand the world if I've never come in contact with so much of it?"( $\log 15)$.

Transformative learning, according to Bourn (2014, p.30) requires "challenging assumptions we all may have, particularly stereotypes, asking ourselves why we have them and what they are based on; from this engagement starting a process of ongoing debate and discussion that could lead to shared enquiry; learner re-considering their own worldview." He emphasises that the process of reflection and reconsideration as the goals.

The limitation of this study is, however, that the study course was an optional one, meaning that those students (and also university faculty) who were interested in the topic chose to participate and reflect in the form of learning journals. Therefore, to some extent the positive and significant learning experiences analysed here need to be interpreted in a context of motivated participants, interested in global issues of education. Thus ready for constructing global connectedness. A critical question is could a dialogic approach and transformative approach to learning make a difference in a context with participants not interested in the topic and cross-cultural encounters. Another concern is that positive intention may not be easy to convert into positive action or to sustain.

\section{Conclusion}

The study explores how sense of global connectedness can be enhanced through creating 
opportunities for cross-cultural dialogue in higher learning. The results emphasise the importance and added value of diversity (geographical, disciplinary, cultural, social) of students and faculty staff engaged in university level programmes in education. Students' significant learning experiences and conducive activities and contexts analysed in this study suggest that creating opportunities for global dialogue and knowledge generation in higher education can open up new perspectives to students in education and thereby increase their sense of global connectedness. The research findings contribute to the development of international study programmes and enhance inclusion of global issues in higher education policies, curricula and practice.

The move from internationalization to global dimensions requires higher education institutions and programmes refocus their core tasks. Learning dialogue that invites and encourages participation of a wide range of learners (including students, faculty and invited presenters) to share, act and reflect on their experiences creates a space for meaningful learning and prepares us for the interconnected world. Cross-cultural learning dialogue is a challenging, critical and thrilling endeavour - and can be deeply meaningful. More needs to be done, however, to better understand global connectedness and the kind of learning activities and contexts that enhance it. In Jyväskylä, Finland, the Faculty of Education has continued organising international participatory seminars with students, faculty and collaboration partners. We believe that our task is to prepare future professionals with deep understanding of the added value of diversity and with significant learning experiences in cross-cultural dialogue and global connectedness. How students' enthusiasm and significant learning are sustained and re-created may be revealed in the next student cohorts' learning journals.

\section{References}

Bakhtin, M. 1981. The dialogic imagination. Austin: University of Texas 
Bennett, R., Volet, S. and Fozdar, F. 2013. "'I'd Say it's Kind of Unique in a Way:' the development of an intercultural student relationship." Journal of Studies in International Education, 17(5), 533-553.

Biesta, G. 2013. The idea of educational theory. In B.J. Irby, G. Brown, R. Lara-Alecio \& S. Jackson (eds). Handbook of educational theories (pp. 5-16). Charlotte, NC: Information Age

Biesta, G., and N.C. Burbules. 2003. Pragmatism and educational research. Lanham, MD: Rowman \& Littlefield.

Bourn, D. 2010. "Students as Global Citizens." In Internationalisation and the Student Voice. Higher Education Perspectives, edited by E. Jones, 18-29. New York: Taylor and Francis.

Bourn, D. 2011. "Discourses and Practices around Development Education: From Learning about Development to Critical Global Pedagogy". Policy and Practice: A Development Education Review, 13 (Autumn): 11-29.

Bourn, D. 2014. The Theory and Practice of Global Learning. Research Paper No.11. London: Development Education Research Centre, Institute of Education in partnership with the Global Learning Programme. http://www.ioe.ac.uk/DERC_ResearchPaper11TheTheoryAndPracticeOfGlobalLearning.pdf (Accessed 17 April 2014).

Braun, V., \& Clarke, V. 2006. Using thematic analysis in psychology. Qualitative research in psychology, 3(2), 77-101.

Crosling, G., N. Mahendhiran and S. Vaithilingam. 2014. "A creative learning ecosystem, quality of education and innovative capacity: a perspective from higher education." Studies in Higher Education, Doi: 10.1080/03075079.2014.881342.

Dewey, J. 1922. Human nature and conduct. Southern Illinois University Press, 1988.

EUA (European University Association). 2007. Creativity in the European Higher Education: report on the EUA creativity project 2006-2007. http://www.eua.be/fileadmin/user_upload/files/Publications/Creativity_in_higher_education.p df (Accessed 15 April 2014).

European Multi-Stakeholder Steering Group on Development Education. 2010. European Development Education Monitoring Report "DE Watch". http://www.coe.int/t/dg4/nscentre/ge/DE_Watch.pdf (Accessed 15 April 2014).

Denson, N. and N. Bowman. 2013. "University diversity and preparation for a global society: the role of diversity in shaping intergroup attitudes and civic outcomes." Studies in Higher Education, 38:4, 555-570, Doi: 10.1080/03075079.2011.584971

Fink, L.D. 2013. Creating Significant Learning Experiences: An integrated approach to designing college courses. San Francisco: Wiley and Sons.

Gargano, T. 2009. "(Re) conceptualizing International Student Mobility: the potential of transnational social fields." Journal of Studies in International Education, 13(3), 331-346.

IAU (International association of universities). 2012. Affirming Academic Values in Internationalisation of Higher Education: A Call for Action. http://www.iauaiu.net/sites/all/files/Affirming_Academic_Values_in_Internationalisation_of_Higher_Educat ion.pdf (Accessed 15 April 2014).

Istance, D. and Dummont, H. 2010. Future directions for learning environments in $21^{\text {st }}$ century. In H. Dummont, D. Istance and F. Benavides (eds.), The Nature of Learning: Using Research to Inspire Practice, 317-338. Paris: OECD, Centre for Research and Educational Innovation. http://www.oecd.org/edu/ceri/thenatureoflearningusingresearchtoinspirepractice.htm (Accessed 8 May 2014).

Jon, J-E. 2013. "Realizing Internationalization at Home in Korean Higher Education: promoting domestic students' interaction with international students and intercultural competence." Journal of Studies in International Education, 17, 455-470.

Kehm, B.M. and U. Teichler. 2007. "Research on Internationalisation in Higher Education."Journal of Studies in International Education, 11(3-4): 260-273. 
Klein, J.D. 2013. Making Meaning in a Standards-Based World: Negotiating Tensions in Global Education. The Educational Forum, 77(4), 481-490. Doi: 10.1080/00131725.2013.822044

Lehtomäki, E., H. Janhonen-Abruquah, M.T. Tuomi, M.-A. Okkolin, H. Posti-Ahokas, and P. Palojoki. 2014.’Research to engage voices on the ground for educational development." International Journal of Educational Development, 35 (March), 37-43. Doi: 10.1016/j.ijedudev.2013.01.003.

McLeod, J. 2011. "Student voice and the politics of listening in higher education." Critical Studies in Education, 52(2): 179-189. Doi: 10.1080/17508487.2011.572830.

Merceia, D. 2013. Engaging with student-teachers on reflective writing. In ed. M. Murphy, Social Theory and Education Research. Routledge: London and New York.

Miller-Idriss, C., and Shami, S. 2012. Graduate Student Training and the Reluctant Internationalism of Social Science in the USA. Research in Comparative and International Education, 7(1), 50-60.

Moate, J. (2014). Dialogic struggles and pedagogic innovation. Culture, pedagogy and society, 22 (2), 295-314.

Novak, J. D. and Gowin, D. B. (1984). Learning how to learn. New York: Cambridge University Press.

Novak, J.D. 2002. "Meaningful learning: the essential factor for conceptual change in limited or inappropriate propositional hierarchies leading to empowerment of learners." Science Education, 86(4), 548-571. Doi: 10.1002/sce.10032.

Renshaw, P.D. 2004. "Dialogic learning, teaching and instruction, Theoretical roots and analytical frameworks.” In J. van der Linden and P. Renshaw (Eds.) Dialogic Learning, Shifting Perspectives to Learning, Instruction and Teaching, 1-15. Dordrecht: Kluwer.

Russell, M. and L. Vallade. 2010. "Guided Reflective Journalling: assessing the international study and volunteering experience." In Internationalisation and the Student Voice. Higher Education Perspectives edited by E. Jones, 98-109. New York: Taylor and Francis.

Scheunpflug, A. 2011. "Global Education and Cross-Cultural Learning: A challenge for a researchbased approach to international teacher education." International Journal of Development Education and Global Learning, 3, (3), 29-44.

Schweisfurth, M. 2012. Are Sojourners Natural Comparativists? Critical Perspectives on the Learning Experiences of International Students. Research in Comparative and International Education, 7(1), 81-89.

Seale, J. 2010. "Doing student voice work in higher education: An exploration of the value of participatory methods." British Educational Research Journal, 36(6): 995-1015.

Stromquist, N.P. 2007. Internationalization as a response to globalization: Radical shifts in university environments. Higher Education, 53, 81-105.

Taylor, B., K. Webber and G. Jacobs. 2013. Institutional research in light of internationalization, growths and competition. New directions for institutional research 157, 5-22.

Tian, M. and J. Lowe. 2009. Existentialist internationalisation and the Chinese student experience in English universities. Compare: A Journal of Comparative and International Education, 39(5), 659-676.

Twiner, A., K. Littleton, C. Coffin and D. Whitelock. 2014. "Meaning making as an interactional accomplishment: A temporal analysis of intentionality and improvisation in classroom dialogue." International Journal of Educational Research 63, 94-106.

UNESCO. 2012. Education For All Global Monitoring Report 2012: Putting education to work. http://www.unesco.org/new/en/education/themes/leading-the-internationalagenda/efareport/reports/2012-skills/

Vygotsky, L. S. 1980. Mind in society: The development of higher psychological processes. Harvard university press. 
Välimaa,J., K. Fonteyn, I. Garam, E. van den Heuvel, C. Linza, M. Söderqvist, J.U. Wolff and J. Kolhinen. 2013. An evaluation of international degree programmes in Finland. The Finnish Higher Education Evaluation Council. http://www.kka.fi/files/1822/KKA_0213.pdf.

Wenger, E. 1998. Communities of Practice: Learning, Meaning and Identity. Cambridge:

Cambridge University Press.

Wenger, E. 2003. "Communities of practice and social learning systems." In D. Nicolini, S.

Gherardi and D. Yanow (Eds.) Knowing in Organizations, A Practice-Based Approach, 7699. Armonk, NY: M.E. Sharpe. 
Table 1: Themes of significant learning experiences identified in students' learning journals

\begin{tabular}{|c|c|c|}
\hline Themes & Examples from the learning journals & $\begin{array}{l}\text { Connection with Fink's } \\
\text { taxonomy }\end{array}$ \\
\hline $\begin{array}{l}1 \text { Recognising } \\
\text { limitations of own } \\
\text { understanding and } \\
\text { possibilities to } \\
\text { understand }\end{array}$ & $\begin{array}{l}\text { "How can I understand the world if I've never come in contact } \\
\text { with so much of it? "( } \log 15) \\
\text { "Once we entered the complete darkness of the café, }[\ldots] \text { our } \\
\text { guide helped us to find a nice table. The experience in this café } \\
\text { was extra-ordinary. It was such a good opportunity to get an } \\
\text { image of how blind people could feel. Of course a seeing person } \\
\text { can never clearly understand how it must feel to be blind, but } \\
\text { this café brings us a little closer to understand a blind person's } \\
\text { perception." (log } 40)\end{array}$ & Learning how to learn \\
\hline $\begin{array}{l}2 \text { Being inspired } \\
\text { by the example of } \\
\text { others and } \\
\text { prompted to think } \\
\text { deeper }\end{array}$ & $\begin{array}{l}\text { "It was the first time to "listen" a presentation through Sign } \\
\text { Language, soundless but powerful and touching. He introduced } \\
\text { his five-month exchange experience in Ethiopia." }(\log 3) \\
\text { "To me, this was one of the bravest examples of teacher } \\
\text { education [..] in the whole seminar." }(\log 35)\end{array}$ & $\begin{array}{l}\text { Learning how to learn } \\
\text { Human dimension }\end{array}$ \\
\hline $\begin{array}{l}3 \text { Appreciation of } \\
\text { learning through } \\
\text { innovative } \\
\text { interactional means }\end{array}$ & $\begin{array}{l}\text { "[The participatory theatre in education] opened my eyes better } \\
\text { to see how hard and complicated it can be as a teacher - and } \\
\text { how hard it can be to cope with the students and especially their } \\
\text { parents I also began to really admire good teachers and the effort } \\
\text { and dedication they show for their work." (log 17) } \\
\text { "Drama presentation had really huge influence on me. The form } \\
\text { was absolutely perfect, scenes were played very well and the } \\
\text { discussion was very useful. Suddenly I found that Finnish school } \\
\text { system has also gaps and challenges which has to overcome." } \\
\text { (log 38) }\end{array}$ & Learning how to learn \\
\hline $\begin{array}{l}4 \text { Problematizing } \\
\text { assumptions }\end{array}$ & $\begin{array}{l}\text { "Finland is one of the countries that seems to meet the EFA } \\
\text { goals. However they still have a series of challenges in their } \\
\text { educational system." }(\log 2) \\
\text { "I was not aware about the problems even a nation with } \\
\text { probably the best education system has." }(\log 16)\end{array}$ & $\begin{array}{l}\text { Learning how to learn } \\
\text { Foundational knowledge }\end{array}$ \\
\hline $\begin{array}{l}5 \mathrm{New} \\
\text { understanding }\end{array}$ & $\begin{array}{l}\text { "Among some of critical issues of EFA that I learnt during the } \\
\text { seminar are the facts that a good number of children especially } \\
\text { in sub Saharan Africa do not yet have access to basic education } \\
\text { even though it is free." (log } 1) \\
\text { "[...] that worldwide } 98 \% \text { of the children with disabilities in } \\
\text { developing countries do not attend school. This is a very } \\
\text { impressive and shocking number for me." (log } 40)\end{array}$ & $\begin{array}{l}\text { Foundational knowledge } \\
\text { Application }\end{array}$ \\
\hline $\begin{array}{l}6 \text { Recognising } \\
\text { personal and } \\
\text { shared } \\
\text { responsibility }\end{array}$ & $\begin{array}{l}\text { "What was the most impressive for me in this presentation was } \\
\text { that he asked one key question that who are included in "all" in } \\
\text { the process of EFA. It is a real and huge challenge for all } \\
\text { educators in all over the world that when discussing about } \\
\text { inclusive education, we have to think about an education, no } \\
\text { matter as a teacher, principal, policy maker, or whatever, whom } \\
\text { are we educating?" (log } 3 \text { ) } \\
\text { "What I learned during those presentations from African } \\
\text { countries is that: even they have much bigger problems than we } \\
\text { have in Europe - there is a movement which is exerted to create } \\
\text { a better education system for the children in those countries and } \\
\text { it is necessary that we share our knowledge and support them in } \\
\text { their development." (log 14) }\end{array}$ & $\begin{array}{l}\text { Caring } \\
\text { Human dimension } \\
\text { Integration } \\
\text { Application }\end{array}$ \\
\hline $\begin{array}{l}7 \text { Comprehending } \\
\text { that problems are } \\
\text { contextual, yet } \\
\text { sharing problems } \\
\text { can support the } \\
\text { realisation of the }\end{array}$ & $\begin{array}{l}\text { "The role of teachers }[\ldots] \text { as educators we can actively } \\
\text { participate and contribute towards making learning meaningful } \\
\text { and exciting for all." (log } 5) \\
\text { "I think it is important to have an overview on existing problems } \\
\text { each different country has. Maybe we can learn from each } \\
\text { other." (log } 16)\end{array}$ & $\begin{array}{l}\text { Human dimension } \\
\text { Application } \\
\text { Integration }\end{array}$ \\
\hline
\end{tabular}


need to act and to participate

Table 2: Conducive learning activities and contexts contributing to significant learning experiences. The extent of the contribution is highlighted by colour, the deeper the grey the more important the activity and context for learning according to the students.

\begin{tabular}{|c|c|c|c|c|c|c|}
\hline \multirow[t]{2}{*}{ Conducive learning activities and contexts } & \multicolumn{6}{|c|}{$\begin{array}{l}\text { Themes of significant learning } \\
\text { experiences (described in Table 1) }\end{array}$} \\
\hline & \begin{tabular}{l|l}
1 & 2 \\
\end{tabular} & 3 & 4 & 5 & 6 & \\
\hline $\begin{array}{l}\text { Participatory theatre in education by young actors highlighting } \\
\text { critical issues in the global EFA process with a focus on the } \\
\text { country-specific context of Finland }\end{array}$ & & & & & & \\
\hline $\begin{array}{l}\text { Mixed discussion groups with specific themes, each group } \\
\text { comprising students, faculty and invited presenters from } \\
\text { different universities and partner organizations }\end{array}$ & & & & & & \\
\hline $\begin{array}{l}\text { Cross-cultural encounters, including both a variety of planned } \\
\text { active interactions and informal discussions during coffee } \\
\text { breaks, lunches and dinner and when moving from one activity } \\
\text { to another }\end{array}$ & & & & & & \\
\hline $\begin{array}{l}\text { Presentation in Sign Language by a Finnish deaf university } \\
\text { student on his academic exchange period in Ethiopia and } \\
\text { voluntary work among deaf children who had very limited } \\
\text { access to education }\end{array}$ & & & & & & \\
\hline $\begin{array}{l}\text { Learning Café in small groups with maximally diverse } \\
\text { participants exchanging views on possible solutions to selected } \\
\text { key global and local challenges in the EFA process }\end{array}$ & & & & & & \\
\hline $\begin{array}{l}\text { Dark Café where the participants had refreshments in darkness, } \\
\text { being guided and assisted by young people with visual } \\
\text { disabilities, and instead of talking about disability experienced it }\end{array}$ & & & & & & \\
\hline
\end{tabular}


Appendix 1: Programme of the 2011 International Education For All Seminar: Critical Issues, organized by the Faculty of Education, University of Jyväskylä, Finland

Thursday November 17, 2011

\begin{tabular}{|l|l|}
\hline Time & Activity \\
\hline 9:00-09:30 & $\begin{array}{l}\text { Seminar Opening } \\
\text { Address by the Minister for International Development, Heidi Hautala }\end{array}$ \\
\hline 9:30-10:40 & $\begin{array}{l}\text { Right to Education? } \\
\text { by Theatre in Education }\end{array}$ \\
\hline 10:40-11:15 & Break \\
\hline 11:15-11:50 & $\begin{array}{l}\text { The Global Education For All Process and Persons with Disabilities } \\
\text { Hannu Savolainen, University of Eastern Finland }\end{array}$ \\
\hline 11:50-12:30 & $\begin{array}{l}\text { Critical Issues of the EFA process in Tanzania } \\
\text { Eustella Bhalalusesa, University of Dar es Salaam }\end{array}$ \\
\hline 12:30-13:30 & Lunch \\
\hline 13:30-14:05 & $\begin{array}{l}\text { The Signifance of Education for Ethiopian Deaf Children } \\
\text { Juhana Salonen, FIDIDA/University of Jyväskylä }\end{array}$ \\
\hline 14:05-14:40 & $\begin{array}{l}\text { Participatory Photography as Inquiry: Images of EFA and Inclusion Practices } \\
\text { Andrew Howes and Ian Kaplan, University of Manchester }\end{array}$ \\
\hline 14:40-15:15 & Coffee break \\
\hline 15:15-16:30 & $\begin{array}{l}\text { Theme groups: 1) Drama, 2) Images, 3) Gender, 4) Disability, 5) Inclusion, 6) } \\
\text { Teachers, 7) Early childhood development, 8) Leadership }\end{array}$ \\
\hline 16:30-17:00 & Refreshing walk from Seminaarinmäki Campus to Agora building \\
\hline 17:00-18:30 & $\begin{array}{l}\text { The Finland Phenomenon: Inside the World's Most Surprising School System, film } \\
\text { by Robert Compton }\end{array}$ \\
\hline 18:30-21:00 & Seminar dinner \\
\hline
\end{tabular}

Friday November 18, 2011

\begin{tabular}{|l|l|}
\hline Time & Activity \\
\hline 9:00-10:15 & Learning Café \\
\hline $10: 30-11: 05$ & $\begin{array}{l}\text { Indigenous Knowledges and EFA } \\
\text { Vanessa Andreotti and Cash Ahenakew, University of Oulu }\end{array}$ \\
\hline 11:05-11:40 & $\begin{array}{l}\text { Status and Challenges of the EFA Process in Ethiopia } \\
\text { Tirussew Teferra, Addis Ababa University }\end{array}$ \\
\hline $11: 40-12: 15$ & $\begin{array}{l}\text { Critical issues of the EFA process in China: Teachers } \\
\text { Mary Yan Feng, Shaoxing University }\end{array}$ \\
\hline $12: 15-13: 15$ & Lunch \\
\hline $13: 15-13: 50$ & $\begin{array}{l}\text { Teachers education in Bosnia and Herzegovina: From the past to present } \\
\text { Snjezana Susnjara, University of Sarajevo }\end{array}$ \\
\hline $13: 50-14: 25$ & $\begin{array}{l}\text { Can Teacher Education Respond to Education for All? } \\
\text { Sai Väyrynen, University of Lapland }\end{array}$ \\
\hline $14: 25-15: 25$ & $\begin{array}{l}\text { Theme groups: 1) Drama, 2) Images, 3) Indigenous Knowlegde, 4) Disability, 5) } \\
\text { Inclusion, 6) Teachers, 7) Early childhood development, 8) Leadership }\end{array}$ \\
\hline $15: 25-16: 00$ & $\begin{array}{l}\text { Interview with Inclusive Education Laureates: } \\
\text { Onerva Mäki, University of Jyväskylä } \\
\text { Tirussew Teferra, University of Addis Ababa } \\
\text { Closing the seminar }\end{array}$ \\
\hline
\end{tabular}


